\title{
AKTIVITAS ANTIBAKTERI ACTINOMYCETES ASAL DESA CEMPAKA KAPUAS HULU KALIMANTAN BARAT TERHADAP ENTEROPATOGENIK GASTROENTERITIS
}

\section{ANTIBACTERIAL ACTIVITY OF ACTINOMYCETES ISOLATED FROM CEMPAKA VILLAGE, KAPUAS HULU DISTRICT, WEST KALIMANTAN AGAINST ENTEROPATHOGENIC GASTROENTERITIS}

\author{
Abdullah, Ihsan Almuhardi, Antoni, Rahmawati* \\ Universitas Tanjungpura, Jl. Prof. Dr. H. Hadari Nawawi Pontianak, 78124 Kalimantan Barat \\ *Corresponding author: rahmawati@fmipa.untan.ac.id
}

Naskah Diterima: 6 Juli 2019; Direvisi: 19 Desember 2019; Disetujui: 29 Januari 2020

\begin{abstract}
Abstrak
Antibiotik yang digunakan secara tidak tepat dapat meningkatkan jumlah bakteri penyebab gastroenteritis yang resisten terhadap antibiotik. Beberapa kelompok mikroorganisme tanah diketahui memiliki potensi menghasilkan senyawa aktif untuk menghambat dan membunuh bakteri patogen, seperti Actinomycetes. Tujuan dari penelitian ini adalah untuk mengetahui potensi antibiotik Actinomycetes terhadap bakteri penyebab gastroenteritis yang diisolasi dari sawah tandus di Desa Cempaka Baru, Kabupaten Kapuas Hulu, Kalimantan Barat. Proses penelitian dilakukan dari isolasi Actinomycetes dari sawah tandus, karakterisasi, serta pengujian kemampuan antibiotik terhadap bakteri Escherichia coli ATCC 25922, Salmonella enterica ATCC 14028 dan Staphylococcus aureus ATCC 25923 menggunakan metode sumuran pada media Mueller Hinton Agar. Hasil identifikasi berdasarkan karakteristik morfologi koloni, sel, dan biokimia diperoleh 1 isolat bakteri, yaitu genus Nocardia sp. ATS-4.1 yang mampu menghambat pertumbuhan bakteribakteri uji yang dibuktikan adanya rata-rata zona hambat yang terbentuk, yakni 14,51 mm; 16,16 mm; dan 11,10 mm. Hasil uji statistik Friedman diperoleh nilai Asymp. Sig 0,10>0,05, sehingga menunjukkan bahwa pemberian cairan kultur isolat Nocardia ATS-4.1 memberikan pengaruh yang tidak berbeda nyata antara hambatan terhadap bakteri E. coli, S. enterica, dan S. aureus. Hal ini dapat disimpulkan bahwa isolat Nocardia sp. ATS-4.1 berpotensi menghasilkan antibakteri yang setara terhadap bakteri E. coli, S. enterica, dan S. aureus penyebab gastroenteritis.
\end{abstract}

Kata kunci: Actinomycetes; Antibakteri; Gastroenteritis; Nocardia

\begin{abstract}
Incorrect use of antibiotics increases the number of resistant bacteria to gastroenteritis. Soil microorganisms are known to have the potential to produce active compounds to inhibit and kill pathogenic bacteria, for example, Actinomycetes. The purpose of this study was to determine the potential of antibiotics produced by Actinomycetes isolated from rice fields in Cempaka Baru, Kapuas Hulu Regency, West Kalimantan, against gastroenteritis bacteria. The research order was carried out by isolating Actinomycetes from barren rice fields, and then characterizing and testing the ability of antibiotics against Escherichia coli ATCC 25922, Salmonella enterica ATCC 14028, and Staphylococcus aureus ATCC 25923 using the well method on Mueller Hinton Agar. The identification results based on morphological characteristics of colonies, cells and biochemistry showed that one of the bacteria was from genus Nocardia sp. ATS-4.1 which was able to inhibit the three test bacteria by the average inhibition zone $14.51 \mathrm{~mm} ; 16.16 \mathrm{~mm}$; and 11.10 $\mathrm{mm}$, respectively. Friedman's statistical test resulted in values asymp. sig 0.10>0.05, which showed that the isolate gave inhibition differences insignificantly among the bacteria. In conclusion, isolate Nocardia sp. ATS-4.1 able to produce similar antibacterial activity against bacteria E. coli, S. enterica and S. aureus caused gastroenteritis.
\end{abstract}

Keywords: Actinomycetes; Antibacterial; Gastroenteritis; Nocardia

Permalink/DOI: http://dx.doi.org/10.15408/kauniyah.v13i1.11731 


\section{PENDAHULUAN}

Kasus penyakit yang disebabkan oleh infeksi mikroorganisme terus meningkat setiap tahunnya, sehingga menjadi ancaman yang serius bagi kesehatan masyarakat, misalnya gastroenteritis. Gastroenteritis atau yang biasa dikenal dengan istilah diare pada umumnya disebabkan oleh mikroorganisme enteropatogen seperti Escherichia coli, Salmonella enterica, dan Staphylococcus aureus. Menurut data profil kesehatan Indonesia tahun 2018 terdapat sekitar 7.157.483 orang dengan kategori semua kalangan umur yang menderita penyakit diare (Kementerian Kesehatan, 2018). Penyakit ini diobati dengan cara pemberian antibiotik, namun sekitar 40-62\% antibiotik digunakan secara tidak tepat, sehingga meningkatkan angka resistensi bakteri terhadap antibiotik (Kementerian Kesehatan, 2014). Adanya kasus resistensi terhadap obat dari bakteri patogen menjadi ancaman besar, sehingga perlu dilakukan kajian terhadap senyawa antimikroorganisme baru yang bersumber dari alam bagi bidang farmasi (World Health Organization, 2014). Berbagai macam penelitian telah dilakukan sebelumnya untuk mengendalikan bakteri patogen dan mengidentifikasi jenis-jenis agen antimikroorganisme terbaru untuk mengatasi hal ini (Ganesan et al., 2017). Bakteri tanah yang sering dilakukan eksploitasi dengan tujuan untuk mengetahui kemampuannya sebagai sumber obat alam terbaru adalah Actinomycetes.

Actinomycetes merupakan kelompok bakteri yang telah diketahui memiliki kemampuan untuk menghasilkan senyawa antibakteri, sekitar 50\% yang telah digunakan selama kurang lebih lima dekade terakhir (Berdy, 2005). Habitat asli Actinomycetes berada pada lingkungan tanah dengan keadaan ekstrim, seperti tingkat kekeringan, suhu, serta kadar keasaman yang relatif lebih tinggi. Keberadaan bakteri kelompok Actinomycetes sangat dipengaruhi oleh beberapa faktor seperti tipe dan karakteristik tanah, serta derajat keasaman $(\mathrm{pH})$. Sharma, Kalita, dan Thakur (2016) berhasil mengisolasi dan menguji aktivitas antibakteri kelompok Actinomycetes dari tanah persawahan PB-52 yang memiliki kemampuan untuk menghambat pertumbuhan bakteri E. coli dan S. aureus dengan rata-rata zona hambat sebesar $31 \mathrm{~mm}$ dan $29 \mathrm{~mm}$. Adegboye dan Babalola (2015) telah melakukan penelitian yang menunjukkan isolat Actinomycetes PKS-II memiliki aktivitas antibakteri terhadap E. coli. Kavitha, Prabhakar, Vijayalakshmi, dan Venkateswarlu (2009) menyatakan bahwa terdapat dua jenis senyawa bersifat antibakteri yang dihasilkan oleh Actinomycetes, seperti bis-(2-ethylhexyl) phthalate dan bis-(5-ethylheptyl), yang efektif menghambat pertumbuhan bakteri $E$. coli dan $S$. enterica. Hal-hal tersebut menunjukkan bahwa bakteri kelompok Actinomycetes berpotensi menghasilkan antibiotik terhadap bakteri enteropatogen gastroenteritis.

Kabupaten Kapuas Hulu merupakan bagian wilayah kecil dari Provinsi Kalimantan Barat. Sebagian kecil topografi jenis tanah di Kapuas Hulu tersusun oleh tanah gambut dari jenis oligotrop dengan luas area sekitar 552.000 hektar atau sekitar $18,5 \%$ dari luas keseluruhan wilayahnya. Wilayah ini sering digunakan aktivitas masyarakat untuk bertanam padi dengan sistem sawah kering. Akan tetapi, sifat dari tanah ini yang tipis serta cekaman $\mathrm{pH}$ yang relatif tinggi berasal dari pelapukan material organik tanah dan miskin unsur hara, seperti di Desa Cempaka (Hikmatullah, Suharta, \& Hidayat, 2008). Lahan gambut yang berada di lahan sawah tandus di Desa Cempaka merupakan salah satu tanah yang memiliki karakter unik berupa cekaman $\mathrm{pH}$ yang relatif rendah. Kisaran tingkat keasaman adalah antara 3-4 (Agus, 2008). Akan tetapi, proses pembentukan tanah gambut tidak terlepas dari aktivitas mikroorganisme tanah yang membantu proses pelapukan bahan-bahan organik, seperti bakteri kelompok Actinomycetes. Oleh karena itu, perlu dilakukan isolasi Actinomycetes untuk mencari isolat yang berpotensi sebagai penghasil antibiotik dari lahan sawah tandus di Desa Cempaka, Kecamatan Pengkadan, Kabupaten Kapuas Hulu, Kalimantan Barat.

\section{MATERIAL DAN METODE}

Bahan yang digunakan adalah Sabouraud Dextrose Agar (SDA) OXOID, Sabouraud Dextrose Broth (SDB) OXOID, medium Starch Casein Agar (dikalium fosfat $\left(\mathrm{K}_{2} \mathrm{HPO}_{4}\right)$, kalium nitrat $\left(\mathrm{KNO}_{3}\right)$, magnesium sulfat heptahidrat $\left(\mathrm{MgSO}_{4} .7 \mathrm{H}_{2} \mathrm{O}\right)$, besi (II) 
heptahidrat sulfat $\left(\mathrm{FeSO}_{4} .7 \mathrm{H}_{2} \mathrm{O}\right)$, kalsium karbonat $\left(\mathrm{CaCO}_{3}\right)$, natrium klorida $(\mathrm{NaCl})$, agar, soluble starch, akuades, barium klorida $\left(\mathrm{BaCl}_{2}\right)$, asam sulfat $\left(\mathrm{H}_{2} \mathrm{SO}_{4}\right)$, media Mueller Hinton Agar (MHA) HIMEDIA, media Triple Sugar Iron Agar (TSIA) OXOID, media Oxidative Fermentative Agar OXOID, media Motility Indole Ornithin Agar (MIO) OXOID, Simmons Citrate Agar (SCA) OXOID, indikator oxidase stripe, media Christensen's urea agar, methylene blue, glukosa, alkohol $70 \%$, kloramfenikol, isolat bakteri E. coli ATCC 25922, S. enterica ATCC 14028, dan $S$. aureus ATCC 25923.

\section{Pengambilan Sampel}

Pengambilan sampel dalam penelitian ini dilakukan di kawasan lahan sawah tandus di Desa Cempaka Baru, Kecamatan Pengkadan, Kabupaten Kapuas Hulu Kalimantan Barat. Pada lokasi yang dipilih selanjutnya diambil tanahnya pada kedalaman 10-15 cm dari permukaan tanah. Sampel tanah dari 2 (dua) titik lokasi tersebut dikompositkan dan dimasukkan ke dalam kotak penyimpanan, lalu dibawa ke laboratorium.

\section{Isolasi Bakteri}

Sebanyak 10 g sampel dimasukkan ke dalam $90 \mathrm{~mL}$ akuades steril. Kemudian diambil sebanyak $1 \mathrm{~mL}$ dan dimasukkan ke dalam $9 \mathrm{~mL}$ larutan garam fisiologis sebagai pengenceran $10^{-1}$. Lalu dari pengenceran $10^{-1}$ diambil $1 \mathrm{~mL}$, dan dimasukkan ke dalam $9 \mathrm{~mL}$ larutan garam fisiologis sebagai pengenceran $10^{-2}$. Pengenceran dilakukan sampai $10^{-6}$ menggunakan larutan garam fisiologis. Sebanyak $1 \mathrm{~mL}$ dari hasil pengenceran $10^{-1}$, $10^{-2}, 10^{-3}, 10^{-4}, 10^{-5}$, dan $10^{-6}$ dituang ke cawan petri kemudian ditebarkan di atas permukaan media Starch Casein Agar (SCA) yang telah memadat menggunakan metode sebar (spread plate method), lalu diinkubasi pada suhu $37^{\circ} \mathrm{C}$ selama 5-7 hari (Balakrishna, Shanker, \& Pindi, 2012).

\section{Pemurnian Bakteri Actinomycetes}

Koloni Actinomycetes yang telah tumbuh, kemudian dimurnikan dengan ditumbuhkan kembali pada media SCA. Pemurnian dilakukan dengan cara diambil sebanyak 1 ose miselium dari Actinomycetes untuk selanjutnya diinokulasikan pada medium
SCA, kemudian diinkubasi suhu $37{ }^{\circ} \mathrm{C}$ selama 5-7 hari.

\section{Peremajaan Bakteri Uji}

Bakteri uji yang terdiri dari $S$. aureus ATCC 25923, E. coli ATCC 25922, dan $S$. enterica ATCC 14024, masing-masing diambil sebanyak 1 (satu) ose lalu diinokulasikan pada permukaan media NA menggunakan metode gores yang selanjutnya diinkubasi pada suhu $37^{\circ} \mathrm{C}$ selama 24 jam.

\section{Karakterisasi Isolat Actinomycetes \\ Pengamatan Makroskopis dan Mikroskopis}

Isolat murni Actinomycetes diamati karakter morfologi koloni secara makroskopis meliputi bentuk, tepian, elevasi, warna miselium aerial dan warna miselium substrat dari koloni (Sharma, Agarwal, Mehtani, \& Bhatnagar, 2014a). Selain itu, kultur sel diwarnai dengan prosedur pewarnaan Gram mengikuti Pelczar dan Chan (2005) untuk diamati reaksi Gram.

\section{Identifikasi Isolat dengan Uji-uji Biokimia}

Tahap identifikasi berdasarkan karakter isolat bakteri yang telah diperoleh mengacu pada buku acuan identifikasi Bergey's Manual of Determinative Bacteriology (Holt, Krig, Sneath, \& Staley, 1994). Uji-uji biokimia yang dilakukan terdiri atas uji katabolisme karbohidrat, oksidatif fermentatif, motilitas, indol, ornitin, sitrat, katalase, oksidase, dan urease (Waluyo, 2008). Uji katabolisme karbohidrat dilakukan dengan cara menumbuhkan bakteri pada media uji Triple Sugar Iron Agar (TSIA) dan manitol agar. Untuk medium TSIA dilakukan dengan ditusukkan 1 ose kultur murni isolat ATS-4.1 ke bagian dasar (butt) dan sisi miring (slant), sedangkan untuk media manitol agar dimasukkan sebanyak 1 ose dari kultur murni isolat Nocardia sp. ATS-4. Kemudian diinkubasi di dalam inkubator pada suhu $37^{\circ} \mathrm{C}$ selama 24 jam. Pada media TSIA, perubahan warna menjadi kuning pada bagian butt dan merah pada bagian slant berarti bakteri mampu memfermentasi glukosa, sedangkan bagian butt dan slant yang berwarna kuning menandakan bakteri mampu melakukan proses fermentasi terhadap laktosa dan sukrosa, serta ditandai lagi dengan terbentuknya gas $\mathrm{H}_{2} \mathrm{~S}$ dan 
$\mathrm{CO}_{2}$ dengan karakteristik bagian dasar media pecah dan terangkat. Pada media manitol agar, hasil positif ditandai dengan terbentuknya gas yang terperangkap di dalam tabung durham.

Uji oksidatif fermentatif dilakukan dengan ditusukkan 1 ose dari kultur murni isolat ATS-4.1 ke dalam media oksidatif fermentatif (OF) agar sebanyak 2 tabung reaksi. Kemudian diinkubasi di dalam inkubator dengan suhu $37{ }^{\circ} \mathrm{C}$ selama 24 jam hingga 48 jam. Tabung reaksi pertama ditetesi menggunakan parafin, sedangkan yang kedua tidak diberi parafin. Hasil positif ditandai dengan perubahan media dari warna hijau menjadi kuning. Apabila hanya pada tabung pertama terjadi perubahan warna menjadi kuning, bakteri tersebut mampu melakukan proses fermentasi, sedangkan jika hanya pada tabung kedua, bakteri tersebut mampu melakukan oksidasi. Jika terjadi perubahan warna terhadap kedua tabung tersebut, bakteri tersebut mampu melakukan proses oksidasi dan fermentasi terhadap gula.

Uji motilitas, indol, dan ornitin dilakukan dengan ditusukkan 1 ose kultur murni isolat ATS-4.1 ke dalam media Motility Indole Ornithin (MIO), kemudian diinkubasi pada suhu $37{ }^{\circ} \mathrm{C}$ selama 24 jam. Hasil positif pada uji motilitas ditandai dengan adanya sebaran pada daerah berkas tusukan, sedangkan pada ornitin terjadi perubahan warna media menjadi berwarna ungu kehitaman secara keseluruhan. Pada uji indol dilakukan penetesan sebanyak 2-3 tetes reagen Kovac's kemudian diinkubasi kembali selama 24 jam, sehingga hasil positif ditandai dengan terbentuknya pola seperti cincin berwarna merah bata hingga hitam pada permukaan media.

Uji sitrat dilakukan dengan digoreskan 1 ose kultur murni isolat ATS-4.1 secara zig-zag pada media Simon Citrate Agar (SCA), kemudian diinkubasi pada suhu $37{ }^{\circ} \mathrm{C}$ selama 24 jam. Hasil positif ditandai dengan perubahan warna media dari hijau menjadi biru.

Uji katalase dilakukan dengan ditetesi 1 ose kultur murni isolat ATS-4.1 menggunakan larutan hidrogen peroksida $\left(\mathrm{H}_{2} \mathrm{O}_{2}\right)$ di atas kaca preparat. Hasil positif ditandai dengan terbentuknya gelembung-gelembung gas.

Uji oksidase dilakukan dengan dioleskan 1 ose kultur murni isolat ATS-4.1 pada bagian indikator oxidase stripe. Hasil positif jika terjadi perubahan warna pada indikator menjadi coklat atau hitam.

Uji urease dilakukan dengan digoreskan 1 ose kultur murni isolat ATS-4.1 secara zigzag pada media Christensen's urea agar. Hasil positif ditandai dengan adanya perubahan warna pada media menjadi merah jambu.

\section{Uji Aktivitas Antibakteri Isolat Actinomycetes Persiapan Bakteri Uji}

Sebanyak 1 ose isolat bakteri E. coli ATCC 25922, S. enterica ATCC 14028, dan $S$. aureus ATCC 25923 diinokulasikan pada medium Nutrient Broth dan diinkubasi pada suhu $37{ }^{\circ} \mathrm{C}$ selama 24 jam. Kemudian diambil beberapa ose, lalu diencerkan dengan larutan garam fisiologis $0,9 \%$ sampai kekeruhan bakteri sama dengan standar McFarland dengan standar 0,5 (Harley \& Prescott, 2002).

\section{Pemisahan Cairan Kultur Actinomycetes}

Sebanyak 2 ose koloni isolat bakteri anggota Actinomycetes diinokulasi pada $50 \mathrm{~mL}$ media SCB ke dalam erlenmeyer $100 \mathrm{~mL}$, lalu diinkubasi pada shaker dengan kecepatan 150 rpm selama 5 hari pada suhu ruangan (Alimuddin, Widada, Asmara, \& Mustofa, 2011). Hasil kultur 5 hari disebut sebagai kultur starter. Sebanyak $5 \mathrm{~mL}$ kultur starter isolat bakteri anggota Actinomycetes diinokulasikan ke dalam $50 \mathrm{~mL}$ SCB lalu diinkubasi pada shaker dengan suhu kamar selama 14 hari. Kemudian kultur dipindahkan ke dalam centrifuge tube dan disentrifugasi dengan kecepatan 3.000 rpm selama 15 menit. Setelah proses sentrifugasi selesai, terbentuk dua bagian lapisan, yakni supernatan (bagian atas) dan pellet (bagian bawah). Lapisan supernatan diambil sebagai sumber metabolit sekunder (Mulyadi \& Sulistyani, 2013; Sharma et al., 2016).

\section{Pengujian Aktivitas Antibakteri Isolat Actinomycetes}

$\begin{array}{cccr}\text { Cairan kultur } & \text { (supernatan) isolat } \\ \text { Actinomycetes } & \text { yang telah didapatkan }\end{array}$ digunakan untuk pengujian antibakteri terhadap bakteri anggota spesies E. coli ATCC 25922, S. enterica ATCC 14028, dan S. aureus ATCC 25923 pada media Mueller Hinton Agar (MHA). Cairan kultur diambil sebanyak $25 \mu \mathrm{L}$ 
lalu dimasukkan ke dalam masing-masing sumur berdiameter $6 \mathrm{~mm}$, dengan kontrol menggunakan kloramfenikol sebanyak 0,25 $\mu \mathrm{g} / \mathrm{mL}$ sebagai kontrol positif antibiotik dengan spektrum luas (National Center for Biotechnology Information, 2019), serta akuades steril sebagai kontrol negatif (tanpa zat antibakteri) pada media MHA yang sebelumnya telah diinokulasikan bakteri uji. Selanjutnya diinkubasi selama 24 jam pada suhu $37{ }^{\circ} \mathrm{C}$. Zona hambat (clear zone) yang terbentuk diukur menggunakan jangka sorong satuan milimeter. Hasil pengukuran zona hambatan dikategorikan sebagai berikut: $<5$ $\mathrm{mm}$ tergolong lemah, 5-10 $\mathrm{mm}$ tergolong sedang, 11-19 tergolong kuat dan $\geq 20 \mathrm{~mm}$ tergolong sangat kuat (Harley \& Prescott, 2002; Kumala, Jayuska, \& Ardiningsih, 2015).

\section{Analisis Data}

Data yang diperoleh dilakukan analisis secara deskriptif berdasarkan karakteristik morfologi koloni, morfologi sel, karakteristik biokimia. Data hasil pengukuran diameter zona hambat (clear zone) yang terbentuk dianalisis menggunakan uji Friedman dengan taraf kepercayaan sebesar 0,05 .

\section{HASIL}

\section{Identifikasi Isolat Actinomycetes}

Berdasarkan penelitian yang telah dilakukan, diperoleh 1 isolat lokal dengan kode ATS4-1 dari wilayah tanah persawahan di desa Cempaka, Kabupaten Kapuas Hulu, Kalimantan Barat. Berdasarkan hasil identifikasi karakteristik morfologis koloni, mikroskopis sel dan uji-uji biokimia, isolat ini merupakan bakteri anggota genus Nocardia (Tabel 1, dan Gambar 1).

Tabel 1. Karakteritik isolat ATS-4.1 berdasarkan karakter makroskopis koloni, mikroskopis dan biokimia

\begin{tabular}{|c|c|c|}
\hline $\begin{array}{l}\text { Karakter makroskopis koloni, } \\
\text { mikroskopis dan biokimia sel }\end{array}$ & Isolat ATS-4.1 & $\begin{array}{l}\text { Genus Nocardia } \\
\text { (Holt et al., 1994) }\end{array}$ \\
\hline \multicolumn{3}{|l|}{ Morfologi koloni } \\
\hline - Bentuk & Granular & Granular \\
\hline - Warna & Abu-abu & Abu-abu \\
\hline - Tepian & Berbenang & Berbenang \\
\hline - Elevasi & Melengkung & Melengkung \\
\hline - Pigmentasi & Abu-abu & Abu-abu \\
\hline - Miselium aerial & Coklat tua & Coklat tua \\
\hline - Miselium substrat & Coklat muda & Coklat muda \\
\hline \multicolumn{3}{|l|}{ Morfologi sel } \\
\hline - Gram & Positif (+) & Positif (+) \\
\hline \multicolumn{3}{|l|}{ Biokimia } \\
\hline - Indol & - & - \\
\hline - Motility & - & - \\
\hline - Ornitin & - & - \\
\hline - Sukrosa & + & + \\
\hline - Manitol & + & + \\
\hline - Sitrat & - & - \\
\hline$-\mathrm{H}_{2} \mathrm{~S}$ & - & - \\
\hline - Inositol & - & - \\
\hline - Laktosa & - & - \\
\hline - Oksidatif-Fermentatif & $\mathrm{O} / \mathrm{F}$ & $\mathrm{O} / \mathrm{F}$ \\
\hline - Urease & + & + \\
\hline - Katalase & + & + \\
\hline - Oksidase & + & + \\
\hline
\end{tabular}

Keterangan : $-=$ Negatif $;+=$ Positif; $\mathrm{O}=$ Oksidatif; $\mathrm{F}=$ Fermentatif 

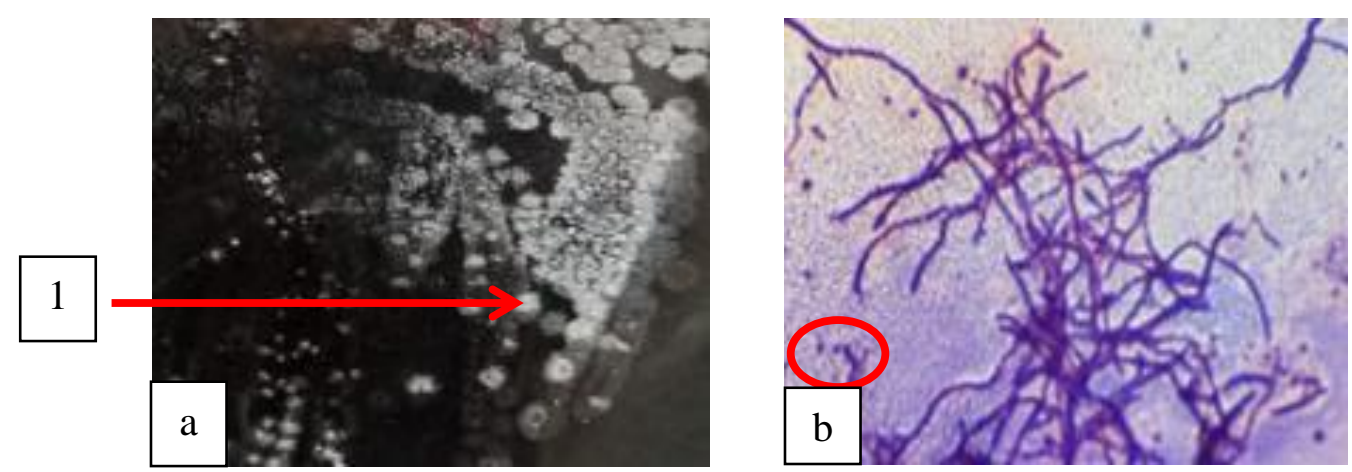

Gambar 1. Bentuk koloni Nocardia pada media Simon Citrate Agar (SCA) (a), mikroskopis Nocardia dengan chain hyphae (b). 1: hifa aerial

Bakteri genus Nocardia memiliki karakter identifikasi kunci secara biokimia, yakni menunjukkan reaksi positif terhadap uji urease, katalase, dan oksidase. Selain itu, bakteri anggota genus Nocardia sp. dengan kode isolat ATS-4.1 ini terkelompok ke dalam bakteri gram-positif (berwarna ungu) (Gambar 1b) serta hifa aerial yang terlihat berwarna putih (Gambar 1a).

Hasil uji aktivitas antibakteri (Gambar 2) memperlihatkan adanya diameter zona hambat terhadap bakteri $E$. coli, $S$. enterica dan $S$. aureus. Pemberian cairan kultur isolat
Nocardia sp. ATS-4.1 memperlihatkan zona hambat tertinggi terhadap bakteri S. enterica dan terendah terhadap bakteri $S$. aureus. Diameter zona hambat yang terbentuk secara berturut-turut sebesar 14,51 mm, 16,16 mm, dan 11,10 $\mathrm{mm}$ (Tabel 2). Diameter zona hambat pada kontrol menggunakan antibiotik kloramfenikol $0,25 \mu \mathrm{g} / \mathrm{mL}$ sebesar $0 \mu \mathrm{mm}$ terhadap bakteri $S$. enterica dan $S$. aureus, sedangkan pada $E$. coli sebesar $0,35 \mathrm{~mm}$, sehingga dapat dikatakan tidak atau kecil zona hambat yang terbentuk.

Tabel 2. Hasil pengukuran zona hambat aktivitas cairan kultur isolat ATS-4.1 terhadap pertumbuhan bakteri Escherichia coli ATCC 25922, Salmonella enterica ATCC 25924, dan Staphylococcus aureus ATCC 25923

\begin{tabular}{lccc}
\hline \multirow{2}{*}{ Perlakuan } & \multicolumn{3}{c}{ Rata-rata diamater zona hambat cairan kultur isolat Nocardia sp. } \\
\cline { 2 - 4 } & Escherichia coli & Salmonella enterica & Staphylococcus aureus \\
\hline Kloramfenikol (Kontrol +) & 0,35 & 0,00 & 0,00 \\
Kontrol negatif & 0 & 0 & 0 \\
Cairan kultur isolat & 14,51 & 16,16 & 11,10 \\
Nocardia sp. ATS-4.1 & Kuat & Kuat & Kuat \\
Respon hambatan & & & \\
\hline
\end{tabular}

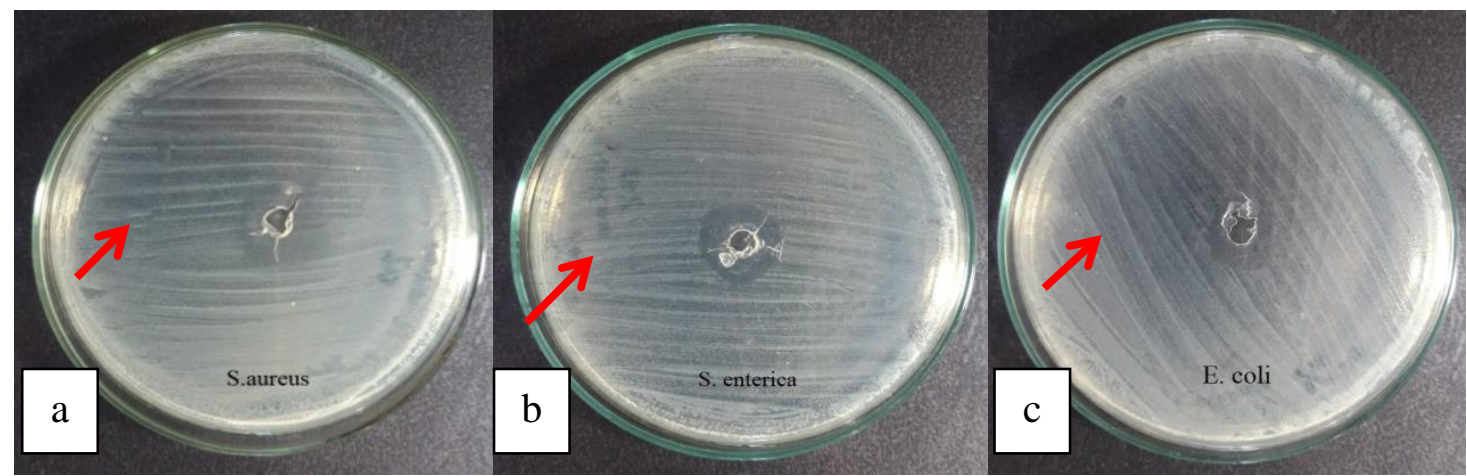

Gambar 2. Zona hambat cairan kultur isolat ATS-4.1 terhadap Escherichia coli (a), Salmonella Enterica (b), Staphylococcus aureus (c) 
Tabel 3. Hasil uji friedman zona hambat aktivitas cairan kultur isolat ATS-4.1 terhadap pertumbuhan bakteri Escherichia coli ATCC 25922, Salmonella enterica ATCC 25924 dan Staphylococcus aureus ATCC 25923

\begin{tabular}{cccc}
\hline $\mathrm{N}$ & Chi-square & Degree free $(\mathrm{df})$ & Asymp. sig \\
\hline 3 & 15,000 & 5 & 0,1 \\
\hline
\end{tabular}

Berdasarkan hasil analisis statistik uji Friedman (Tabel 3) dengan tingkat kepercayaan sebesar 0,05 diperoleh nilai Asymp. Sig $0,1>0,05$, yang menunjukkan bahwa hambatan oleh pemberian cairan kultur isolat Nocardia ATS-4.1 terhadap bakteri E. coli, S. enterica, dan $S$. aureus tidak berbeda secara nyata.

\section{PEMBAHASAN}

\section{Karakteristik Isolat ATS-4.1}

Hasil isolasi bakteri memperoleh satu jenis isolat lokal bakteri Actinomycetes asli (indigenous). Hasil karakterisasi yang telah dilakukan dengan mengacu kepada buku kunci identifikasi Bergey's Manual of Determinative Bacteriology (Holt et al., 1994) mengindikasikan bahwa isolat ATS-4.1 termasuk ke dalam kelompok bakteri anggota genus Nocardia. Bakteri anggota genus Nocardia sp. ATS-4.1 mampu melakukan proses katabolisme karbohidrat berupa gukosa, sukrosa, laktosa, dan manitol, menghasilkan enzim oksidase, katalase, dan urease, tidak memiliki kemampuan untuk memproduksi enzim sitrase, tidak memproduksi senyawa indol dan bersifat nonmotil (Sharma, Dangi, \& Choundhary, 2014b; Sharma et al., 2016). Kemampuan beberapa bakteri anggota genus Nocardia dalam melakukan proses katabolisme karbohidrat didasarkan atas kebutuhan akan unsur karbon yang dipecah dari kelompok karbohidrat. Menurut Haryani, Grandiosa, Buwono, dan Santika (2012), bakteri yang memiliki kemampuan untuk melakukan fermentasi dan degradasi pada dasarnya akan menghasilkan senyawa asam sebagai hasil sampingan metabolisme.

Bakteri anggota genus Nocardia memiliki 3 karakter kunci utama biokimia, yakni reaksi positif pada uji oksidase, katalase, dan urease. Enzim oksidase oleh bakteri anggota genus Nocardia berfungsi untuk membantu proses katalisis reaksi reduksioksidasi yang terjadi di dalam sel (Murray et al., 2009). Enzim katalase berfungsi untuk membantu proses pemecahan komponen senyawa yang memiliki tingkat toksisitas yang tinggi bagi sel, seperti hidrogen peroksida dipecah menjadi komponen air dan oksigen. Menurut Cappucino dan Sherman (2014), enzim katalase yang dihasilkan oleh bakteri memiliki peranan penting bagi proses pertumbuhan aerobik. Proses ini melibatkan pembentukan hidrogen peroksida yang terbentuk dari hasil respirasi sel yang bersifat racun dan mampu membunuh sel hidup. Enzim urease berfungsi untuk memecah beberapa senyawa yang mengandung nitrogen bagi komponen selular. Proses pemecahan ini dimaksudkan agar bakteri mampu menjaga kestabilan kadar nitrogen dan karbon guna mendukung aktivitas selulernya, serta kemampuan membentuk berbagai macam senyawa bagi proses pertahanan. Selain itu, bakteri anggota genus Nocardia bersifat nonmotile, karena tidak memiliki alat gerak berupa flagel. kemampuan bakteri dalam berpindah posisi letak karena keberadaan suatu rangsangan yang berasal dari lingkungan berupa zat kimia sehingga bakteri akan bergerak mendekati arah datangnya rangsangan (Rai, Khadka, \& Shrestha, 2018). Isolat bakteri Nocardia sp. ATS-4.1 yang diperoleh dari habitat tanah gambut oligotrop di Desa Cempaka, Kecamatan Pengkadan, Kabupaten Kapuas Hulu, Kalimantan Barat, dengan kisaran $\mathrm{pH} 3-4$, cenderung memiliki kemampuan untuk memproduksi berbagai macam jenis senyawa bioaktif. Hal ini penting sebagai agen pertahanan diri untuk tetap menjaga eksistensi sel serta menjaga sistem metabolisme berjalan dengan normal. Menurut Harley dan Prescott (2002), bakteri cenderung menghasilkan senyawa bioaktif sebagai agen pertahanan terhadap cekaman $\mathrm{pH}$ yang relatif rendah (asam) serta menjaga agar proses metabolisme berjalan secara normal.

\section{Aktivitas Antibakteri}

Isolat Nocardia ATS-4.1 memperlihatkan kemampuan menghambat pertumbuhan 
bakteri uji yang ditandai oleh adanya zona hambatan yang terbentuk dengan tingkat aktivitas tergolong kuat terhadap bakteri $E$. coli, S. enterica, dan S. aureus (Tabel 2). Terbentuknya zona hambat menandakan bahwa cairan kultur dari isolat Nocardia sp. ATS-4.1 memiliki kandungan senyawa antimikroorganisme yang berdifusi ke permukaan agar. Menurut Bacon et al. (2017), terbentuknya zona hambatan (clear zone) menandakan bahwa suatu mikroorganisme memiliki kemampuan untuk memproduksi senyawa antimikroorganisme. Hal ini menandakan bahwa metabolit sekunder di dalam supernatan memiliki aktivitas antimikroorganisme alami yang dibentuk oleh komponen ekstraseluler sel bakteri genus Nocardia. Menurut Sharma et al. (2016), genus Nocardia memiliki kemampuan menghasilkan 20 jenis senyawa berbeda yang berhasil dipelajari, seperti senyawa fenol seperti 3,5-bis (1,1-dimethylethyl)-phenol dan 2,4-di-tert-butyl-6-nitrophenol, serta beberapa jenis senyawa asam yang berpotensi sebagai senyawa antimikroorganisme yang mampu menghambat pertumbuhan beberapa kelompok bakteri gram-positif, gram-negatif serta kelompok khamir (yeast). Pada penelitian ini, medium pertumbuhan yang digunakan berupa medium cair, yakni SCB. Komponen starch yang menyusun medium pertumbuhan ini memiliki peranan sebagai sumber karbon dan nitrogen utama yang dapat dimanfaatkan oleh bakteri genus Nocardia untuk memproduksi senyawa antimikroorganisme, sehingga akan memengaruhi tingkat kekuatan dari senyawa antimikroorganisme yang dihasilkan. Menurut Dologhazi dan Metcalf (2013), proses pembentukan senyawa antimikroorganisme adalah melalui mesin biosintesis sel, yakni polyketide synthases (PKSs) dan nonribosomal peptide synthetases (NRPSs) yang dikode oleh genom Actinomycetes.

Kontrol menggunakan antibiotik kloramfenikol terhadap E. coli memperlihatkan diameter zona hambat yang lebih kecil daripada cairan kultur, yakni sebesar $0,35 \mathrm{~mm}$, sedangkan terhadap $S$. enterica dan $S$. aureus tidak memperlihatkan zona hambat. Hal ini diduga bakteri tersebut telah berhasil melakukan modifikasi terhadap dinding sel yang tersusun atas peptidoglikan sehingga mampu melawan tingkat toksisitas antibiotik kloramfenikol terhadap sel sehingga sel menjadi lebih resisten. Menurut Brooks, Carroll, Butel, Morse, dan Mietzner (2013), sifat resisten ini juga diakibatkan oleh adanya mekanisme mutasi kromosomal atau transfer DNA, sehingga sifat ini bisa diturunkan kepada generasi berikutnya.

Berdasarkan hasil analisis statistik Friedman (Tabel 3), nilai Asymp. Sig $0,10>0,05$, yang berarti perlakuan pemberian cairan kultur isolat Nocardia sp. ATS-4.1 tidak memberikan perbedaan yang nyata pada penghambatan terhadap pertumbuhan bakteri $E$ coli, $S$. enterica, dan $S$. aureus. Hal ini juga menandakan bahwa isolat Nocardia sp. ATS4.1 memiliki potensi sebagai sumber penghasil antibakteri dengan spektrum luas. Antibakteri spektrum luas merupakan kelompok senyawa antibakteri yang memiliki kemampuan untuk menghambat bahkan membunuh berbagai jenis bakteri gram-positif dan gram-negatif yang berarti memiliki peranan ganda (Sharma et al., 2016).

Mekanisme kerja dari senyawa antibiotik dapat dengan cara merusak dan menembus lapisan dinding sel bakteri dan menjadikan protein yang berada di dalam sel bakteri mengalami denaturasi (Cao, $\mathrm{Xu}, \mathrm{Wu}, \mathrm{Li}, \&$ Chen, 2014). Struktur dinding sel Bakteri gram-positif seperti $S$. aureus hanya memiliki satu lapisan tunggal peptidoglikan yang terdiri atas 1-2 lapisan, sedangkan bakteri gramnegatif seperti $E$. coli dan $S$. enterica memiliki 3 lapisan peptidoglikan yang terdiri dari lapisan luar lipopolisakarida, lapisan tengah dan dalam yang berjumlah kurang lebih 30 lapisan (Dalisay et al., 2013). Senyawa antimikroba akan bergerak masuk ke dalam sel bakteri gram-positif maupun gram-negatif untuk menginaktifkan aktivitas enzim esensial di dalam sel bakteri, walaupun dalam konsentrasi yang rendah sekalipun dengan memutus ikatan peptidoglikan yang berada pada dinding sel, sehingga menerobos masuk ke dalam sel. Setelah bergerak menerobos dinding sel, beberapa senyawa antimikroba seperti fenol akan memutus ikatan hidrofobik komponen membran sel serta larutnya beberapa komponen-komponen seluler yang saling berikatan hidrofobik pada membran sel yang berakibat meningkatkan permeabilitas 
membran, sehingga menyebabkan keluarnya keseluruhan komponen sel (Sharma et al., 2014b; Sharma et al., 2016). Keluarnya keseluruhan isi sel menyebabkan terhambatnya aktivitas dan biosintesis enzim-enzim spesifik yang diperlukan oleh sel bakteri untuk proses metabolisme guna mendukung pertumbuhan dan perkembangan sel (Brooks et al., 2013).

Bakteri anggota genus Nocardia telah dilaporkan memiliki kemampuan dalam memproduksi senyawa-senyawa yang dapat menghambat pertumbuhan bakteri patogen, seperti bakteri Mycobacterium gordonae, dengan menghasilkan senyawa berupa transvalencin A yang diproduksi oleh $N$. transvalensis IFM10065 (Hoshini et al., 2004). Kavitha et al. (2009) juga menyebutkan bahwa dua jenis senyawa aktif seperti bis-(2ethylhexyl) phthalate dan bis-(5-ethylheptyl) phthalate diproduksi oleh $N$. levis MK-.

\section{SIMPULAN DAN SARAN}

Sebanyak satu isolat lokal Actinomycetes berhasil diisolasi dari lahan persawahan Desa Cempaka Baru, Kabupaten Kapuas Hulu, Kalimantan Barat. Berdasarkan hasil uji aktivitas antibakteri terhadap bakteri penyebab gastroenteritis, cairan kultur isolat Nocardia sp. ATS-4.1 memiliki kemampuan menghambat pertumbuhan bakteri $E$. coli, $S$. enterica, dan $S$. aureus penyebab gastroenteritis. Dengan demikian, bakteri Actinomycetes yang berhasil didapatkan ini memiliki peluang dan potensi untuk dikembangkan menjadi salah satu sumber senyawa alternatif berupa antibiotik untuk mengatasi kasus infeksi oleh bakteri patogen.

Saran untuk penelitian selanjutnya adalah perlunya dilakukan identifikasi secara molekuler untuk mengetahui spesies dari bakteri Actinomycetes serta karakterisasi jenis senyawa metabolit sekunder yang dihasilkan untuk menghambat pertumbuhan bakteri patogen.

\section{UCAPAN TERIMA KASIH}

Penulis mengucapkan terima kasih kepada Kementerian Riset, Teknologi, dan Pendidikan Tinggi Republik Indonesia yang telah membantu memberikan pendanaan dalam proses pelaksanaan penelitian ini hingga dapat terselesaikan hingga akhir.

\section{REFERENSI}

Adegboye, M., \& Babalola, O. O. (2015). Evaluation of antibiotic biosynthetic potential of Actinomycetes isolates to produce antimicrobial agents. British Microbiology Research Journal, 7(5), 244-254.

Agus, S. (2008). Lahan gambut potensi untuk pertanian dan aspek lingkungan. Bogor: Balai Penelitian Tanah dan World Agroforestry Center.

Alimuddin., Widada, J., Asmara, W., \& Mustofa. (2011). Antifungal production of a strain of Actinomycetes spp. Isolated from the rhizosphere of cajuput plant: Selection and detection of exhibiting activity against tested fungi. Indonesian Journal of Biotechnologi, 16(1), 1-10.

Bacon, K., Boyer, R., Denbow, C., Keefe, S., Neilson, A., \& Williams, R. (2017). Antibacterial activity of jalapeño pepper (Capsicum annuum var. annuum) extract fractions against select foodborne pathogens. Food Science \& Nutrition, 5(3), 730-738.

Balakrishna, G., Shanker, A. S., \& Pindi, P. K. (2012). Isolation of phosphate solibulizing Actinomycetes from forest soils of Mahabubnagar District. International Organization of Scientific Research Journal of Pharmacy \& Biological Sciences, 2(2), 271-275.

Berdy, J. (2005). Bioactive microbial metabolites. The Journal of Antibiotic, 58(1), 1-26.

Brooks, G. F., Carroll, K. C., Butel, J. S., Morse, S. A., \& Mietzner, T. A. (2013). Medical microbiology. New York: McGraw Hill Lange.

Cao, G., Xu, Z., Wu, X., Li, Q., \& Chen, X. (2014). Capture and identification of the volatile components in crude and processed herbal medicines through online purge and trap technique coupled with GC $\times$ GC-TOF MS. Natural Product Research, 28(19), 1607-1612. Cappucino, J. G., \& Sherman, N. (2014). Microbiology: A laboratory manual. United States of America: Pearson. 
Dalisay, D. S., Williams, D. E., Wang, X. L., Centko, R., Chen, J., \& Raymond, J. (2013). Marine sediment-derived streptomyces bacteria from British, Columbia, Canada are a promising microbiota resource for the discovery of antimicrobial natural products, Plos One, 8(10), 1-14.

Dologhazi, J. R., \& Metcalf, W. W. (2013). Comparative genomics of actinomycetes with a focus on natural product biosynthetic genes. Biomed Central Genomics, 14(611), 1-13.

Ganesan, P., Reegan, A. D., David, R. H. A., Gandhi, M. R., Paulraj, M. G., Aldhabi, N. A., \& Ignacimuthu, S. (2017). Antimicrobial activity of some Actinomycetes from Western Ghats of Tamil Nadu, India. Alexandria Journal of Medicine, 53(2), 101-110.

Harley, J. P., \& Prescott, L. M. (2002). Laboratory exercises in microbiology. New York: Mc-Graw Hill Lange.

Haryani, A., Grandiosa, R., Buwono, I. D., \& Santika, A. (2012). Uji efektivitas daun pepaya (Carica papaya) untuk pengobatan infeksi bakteri Aeromonas hydrophila pada ikan mas koki (Carassius auratus). Jurnal Perikanan \& Kelautan, 3(3), 213-220.

Hikmatullah., Suharta, N., \& Hidayat, A. (2008). Potensi sumberdaya lahan untuk pengembangan komoditas pertanian di provinsi Kalimantan Barat. Jurnal Sumberdaya Lahan, 2(1), 45-58.

Holt, J., Krig, P., Sneath, J., \& Staley, S. (1994). Bergey's manual of determinative bacteriology. United States of America: Springer.

Hoshini, Y., Mukai, A., Yazawa, K., Uno, J., Ishikawa, J., Ando, A., \& Mikami, Y. (2004). A new thiazolidine-type antibiotic with zinc in its structure, designated transvalencin A, was isolated from Nocardia sp. IFM 1006 a clinical isolate from a patient with actinomycotic Nocardia transvalensis. The Journal of Antibiotics, 57(12), 797802.
Kavitha, A., Prabhakar, P., Vijayalakshmi, M., \& Venkateswarlu, Y. (2009). Production of bioactive metabolites by Nocardia levis. Letter in Applied Microbiology, 49(4), 484-490.

Kementerian Kesehatan Republik Indonesia. (2014). Profil kesehatan indonesia. Jakarta: Kementerian Kesehatan Republik Indonesia.

Kementerian Kesehatan Republik Indonesia. (2018). Profil kesehatan indonesia. Jakarta: Kementerian Kesehatan Republik Indonesia.

Kumala, T., Jayuska, A., \& Ardiningsih, P. (2015). Uji awal aktivitas antimikroorganisme dari Actinomycetes 9ISP1 berasosiasi spons. Jurnal Kimia Khatulistiwa, 4(2), 30-36.

Mulyadi., \& Sulistyani, N. (2013). Aktivitas cairan kultur 12 isolat Actinomycetes terhadap bakteri resisten. Kesehatan Masyarakat, 7(2), 89-96.

Murray, R., Bender, D., Botham, K., Kennelly, P., Rodwell, V., \& Weil, P. (2009). Harper's illustrated biochemistry. New York: Mc-Graw Hill Lange.

National Center for Biotechnology Information. (2019). PubChem database of chloramphenicol. (2020, January 19). Retrieved from https://pubchem.ncbi.nlm.nih.gov/comp ound/Chloramphenicol.

Pelczar, E. M., \& Chan, E. (2005). Basic of microbiology. New York: Mc-Graw Hill Lange.

Rai, K., Khadka, S., \& Shrestha, B. (2018). Actinomycetes: Isolation, characterization and screening for antimicrobial activity from different sites of Chitwan, Nepal. International Journal of Microbiology \& Biotechnology, 3(1), 25-30.

Sharma, C., Agarwal, A., Mehtani, P., \& Bhatnagar, P. (2014a). Characterization of Actinomycetes from soil sample of Nahargarh Hill Area, Jaipur, India for production of antimicrobial compounds and enzymes. International Journal of Advanced Biotechnology \& Research, 5(3), 304-312. 
Sharma, M., Dangi, P., \& Choundhary, M. (2014b). Actinomycetes: Source, identification and their applications. International Journal of Current Microbiology \& Applied Sciences, 3(2), 801-832.
Waluyo, L. (2008). Teknik dasar dalam mikrobiologi. Malang: Universitas Muhammadiyah Malang Press.

World Health Organization (WHO). (2014). Antimicrobial resistance: Global health report on surveillance. France: Bulletin of the World Health Organization. 